\title{
CHAPLAINCY INSTITUTE IN UKRAINE AND EU COUNTRIES
}

\author{
YULIIA KRYVENKO \\ Departament of Civil Law, National University "Odessa Academy of Law" \\ Fontan road 23, Odessa, Ukraine \\ E-mail address: uwk1970@ukr.net \\ ORCID: https://orcid.org/0000-0001-7506-0786 \\ OLEKSANDR OMELCHUK \\ Departament of Civil Law, National University “Odessa Academy of Law” \\ Fontan road 23, Odessa, Ukraine \\ E-mail address: olekomel@gmail.com \\ ORCID: https://orcid.org/0000-0002-0082-3619
}

\section{IULIIA CHERNOVALIUK}

Berdiansk State and Municipal Management Institute of Private Classical University

Urickogo street 3, Berdiansk, Ukraine

E-mail address: ju-c@ukr.net

ORCID: https://orcid.org/0000-0002-6918-208X

\begin{abstract}
Aim. The aim of the article is to research of chaplaincy institutes in Ukraine, taking into account the experience of EU countries.

Concept. During the study, the interaction between military service and religion is examined based on a universal socio-cultural tradition, having a complex, multi-level structure, covering the whole socio-institutional level (society - social institutions - social organizations of the individual) and leading to the creation of a specific social structure - a military-religious institute, the institution of the military chaplaincy.

Conclusions. It is found that there are no historical analogies in the world for the creation of a military chaplaincy institute, which makes the present Ukraine experience unique, but to this day the issue of state regulation in the field of pastoral care of military personnel of the Armed Forces of Ukraine and the creation of a military chaplaincy institute remains unregulated. In contrast to Ukraine, the legal support for the existence of an institute of military chaplaincy in Poland is provided by the relevant state normative-legal acts and by-church documents. Most European countries have the opportunity to serve for both military and civilian chaplains. Due to the analysis of legal acts and experience of European countries, it should be determined that Ukraine chooses the "European" model of chaplaincy. The article also identifies the positive aspects of the organizational experience of military chaplaincy as a possible
\end{abstract}


adoption by Ukraine. The notion of a chaplain-volunteer is typical within Ukrainian legislation.

Key words: religion, religious organizations, military priests, chaplaincy, chaplains, chaplains - volunteers.

\section{INTRODUCTION}

$\mathrm{T}$ he issues of interaction between army and religion are quite complex and diverse. According to the study of perception by servicemen of faith in God and their knowledge of the basic religious tenets is only part of this complex of directions interaction. Until recently, the question of the possibility to invite priests into barracks to allow religious figures assume the role of spiritual pastors to servicemen, and whether it is meaningful and necessary to have military priest institutions again, and worship establishments in military units and on warships was quite earnestly debated.

Religion is one of the oldest and most effective means of influencing the individual and society. In the history of various cultures and societies, religion has played an important role as the ideological and moral-ethical regulator of human behaviour. Religious institutions also today remain one of the important parts of modern society, significantly influencing their main social spheres and processes.

The history of the state testifies to the existence of a stable spiritual and religious tradition. In the new socio-historical context, these lost traditions are being revived, religion becomes one of the institutions of the warrior's personality formation, and Armed Forces interaction with religious organizations is established.

However, the situation in our country forces us to look for different ways out and identifying the main priorities that will allow us to build new democratic relations in all areas of our lives. The rapid change in the military-political situation in the world as well as the development of means and methods of armed struggle bring us back to the times when victory was determined mainly by the spiritual and moral forces of the troops. It is obvious that without some reliance on the eternal Christian values, the whole system of spiritual and moral education of servicemen, including officers, can fail.

Unfortunately, the problems that arise in the path of establishing institutions of the military chaplaincy are not only related to gaps in organizational moments, but also to economic and governmental factors (Yurchuk, 2014).

Today, in the painful problems of the Ukrainian army, which have been discussed for a long time by military personnel, priests of different denominations and politicians have become noticeable as never before.

The process of interaction between the Armed Forces of Ukraine and religious organizations in modern conditions is a social mechanism of objectively formed relations, the content of which is a purposeful and coordinated on the legal basis activity of the subjects of the two institutions for achieving effective influence of the institutions and organs of the Church on the spiritual life of military servicemen through the use of optimal means, methods and forms of moral and psychological influence on a voluntary basis, taking into account the 
specific conditions and tasks of the military activity. The normal functioning of this mechanism objectively implies compliance with current legislation, implementation of existing principles and norms of interaction between the army and the church, management and coordination of the activities of the subjects, coordination and control of specific conditions and tasks of the activity, the possibility of influence of other confessions on the spiritual life of servicemen.

Accordingly, on several occasions, attempts have been made at the legislative level to determine the specificity of the interaction of religious organizations with the armed forces through the introduction of the chaplaincy institute. Of course, the issue of chaplaincy in our country is not easy, and it needs careful elaboration, taking into account both our own experience and the experience of foreign countries. There are many opinions and debates about this, in fact, the diversity of religious denominations has no common point of view on issues addressed in the establishment of the military chaplaincy institute in Ukraine. Although, it has been repeatedly stated that every religious community strongly supports the ministry of pastoral souls in military units. In many countries, the quota issue of an interdenominational ministry of chaplains has been resolved.

In Ukraine, this needs to be done as soon as possible, as each of the traditional churches has a long history of pastoral care in Ukraine. The Constitution of Ukraine states in Article 18 that no ideology can be recognized as binding by the state. (Constitution of Ukraine, 1996).

According to the Geneva Conventions (1949), clerics are not considered combatants (non-combatants) and retain this status by being held prisoner, where they have the right to continue their service among prisoners. During military operations, they, as well as doctors, are prohibited by international laws to kill.

Chaplains are defined as "spiritual staff," which means they are persons, both military and civilians, such as priests, who are solely engaged in the performance of their spiritual functions and belong to:

- the armed forces of the party that is in conflict;

- medical units or sanitary vehicles of the party that is in conflict;

- medical units or sanitary vehicles, referred to in article 9, paragraph 2;

- civil defense organizations of the party that is in conflict (Protocol I, 1977).

There has been a law in the UN for a long time that there must be a chaplain in the army. After all, every state has its own model of the military pastor.

The main purpose of this article is to investigate the chaplaincy institute of the Republics of Poland and Ukraine. Hence, we need to solve the following issues:

- to carry out a comparative analysis of the institute of military chaplains in the Republic of Poland and Ukraine;

- $\quad$ identify the strengths and weaknesses of current legislation, according to which to submit proposals aimed at improving legislation that will ensure the proper legal regulation of the activities of military chaplains in Ukraine. 
After the adoption of the 1991 regulations that govern the relationship between the state and religious organizations, in particular, pastoral work started in the armed forces of Ukraine, which led the scientific community to carry out new studies on the subject.

Analysis of recent research and publications which offer a solution of the problem.

Because the topic is on the border of religious studies and law, it should be determined that scientific development regarding the legal status and features of military chaplains is limited to the study of historical domestic and international experience.

\section{THE MAIN MATERIAL}

The history of chaplaincy goes back to the 4th century and is associated with the legendary of meeting St. Martin Tursky with a beggar, to whom St. Martin gave half of his cloak cut with his sword. That night Jesus Christ appeared to him covered with his cloak. The pattern of this cloak (latin - capella) was worn in a battle and its guardian was the capellan (capellanus), the king's priest. Hence the term "chapel" - a place of preservation of the gonfalon, and later worship.

The revival of military chaplains began with volunteers during the open military conflict in eastern Ukraine. Military priests came to the military units and had access to the military, especially as volunteers, through the transfer of urgent humanitarian aid collected through religious communities and community organizations. Because the term originated on the territories, where the western branch of Christianity (Catholicism) dominated, separate authors have not always recognized succession in interpretation.

Therefore, Canon 564 of the Code of Canons of the Catholic Church defines: "A chaplain is a priest, who is entrusted, on a permanent basis, with pastoral care (at least in part) over any community or special group of Christ's believers which carry out duties in accordance with the rules of universal or particular law." And so often, in the countries that emerged after the collapse of the USSR (except the Baltic countries), this term has tried to counter the alternative - "military priest" is something essentially different, which is inappropriate. A military chaplain is associated with a particular denomination and is its representative in the army. He gives spiritual support to people of any religion without imposing on others his own religious views, without giving up his own beliefs at the same time. In the case of Ukraine, the issue of military chaplaincy is complicated by the fact that the religious environment is not homogeneous. The cause of the conflict between chaplains and religious organizations has divided the religious structure of Ukraine.

Therefore, given the polyconfessionality of Ukraine, in practical terms, experience of those countries that resolve the issue of spiritual guardianship of military, taking into account polyconfessionality composition of their society as a whole and armed forces in particular, are primarily of interest. 
There is no single model of a chaplain service organisation in the world; instead, there are different models and types of coordinations between the church and the armed forces of the state. The most widespread basis for the introduction of military chaplaincy is the constitutional articles, resolutions of the government, etc. There also exist concordances, treaties and agreements between the church and the government, so in Poland and Romania there is a legal basis for the interaction between the churches and the army, as well as certain church instructions for such cooperation. In the Czech Republic, Slovakia and Slovenia there are agreements between the church and the Ministry of Defense. In Slovakia, a concordat was signed between the Roman Catholic Church and the government, in Slovenia the interaction is coordinated with the military regulations on chaplaincy, in Lithuania and Hungary, chaplaincy was established by a state concordat with the Roman Catholic Church, and in Estonia the institute of military chaplain is provided for by the National Defense Regulations. By organizational structure, chaplaincy services are divided into two types: ecclesiastical subordination (episcopal) and subordinate to military command (in about $54 \%$ of countries).

In turn, it should be noted that the restoration of the Chaplaincy Institute in Poland began after the adoption on May 17, 1989 of the Laws "On Relations between the State and the Catholic Church in the Republic of Poland" and "On Guarantees of Freedom of Conscience and Confession." The legal norms which defined the foundations of pastoral care in the armed forces of Poland were introduced. In addition, there are fourteen individual laws that contain appropriate legal safeguards that provide for the organization of pastoral care for representatives of certain churches and religious associations in the relevant structures of the Polish army. The norms of these legal acts are directly applicable to the representatives of the following churches and religious organizations: the Polish Catholic Church in the Republic of Poland; The Old Catholic Church in the Republic of Poland; The Polish Autocephalous Orthodox Church; The Old Believers Eastern Church which has no hierarchy; the Evangelical-Augsburg Church in the Republic of Poland; The Evangelical Methodist Church in the Republic of Poland; Baptist Christian Churches in the Republic of Poland; Seventh-day Adventist churches in the Republic of Poland; Pentecostal Church in the Republic of Poland; the union of Jewish religious communities in the republic in Poland; Muslim religious communities in the Republic of Poland; Karaim religious association in the Republic of Poland.

The institute of military chaplaincy in Poland is funded from the state budget, which effects its functioning (Vladichenko, 2013, p. 178). In Romania, there are 80 chaplains, equal to officers, who receive their salaries from the state. Also in the Czech Republic and Slovakia, reserve chaplains are paid for their pastoral service by the armed forces. In the Baltic countries, chaplains are officers (although there are also civilian chaplains in Latvia). In Estonia, chaplains are civil servants, their activities are paid from the state budget (with only members of the churches of the Estonian Council of Churches having the right to serve as chaplains; members of other religious organizations (includ- 
ing non-Christian ones) have access to military institutions at the request of their members). The same applies to Latvia and Lithuania, where a chaplain may be a representative of one of eight Christian denominations.

It is clear that in a well-balanced state (in the legal sphere), the principle of separation of state and church (France) is rather rigid. However, it does not block the activities of the church among the military, and at the same time imposes requirements on chaplains, who in extreme manifestations may be qualified as interfering with the internal sphere of the Church. An example of such actions (at a "smaller" separation, such as in the USA) is the obligation to be a "chaplain for all," regardless of denominational affiliation (even for Satanists), to act in line with the prevailing social ideology, to give sacraments (to perform rites) for LGBT people, etc. Chaplains may also be partially "delegated" to function in a psychological influence (and be given appropriate psychological education). In an unbalanced (in the legal field) state, there is an effort on the part of the military to "take and use" the Church's resources in order to satisfy the internal interests of the Army (to make military more obedient, to improve their level of discipline, etc.).

A serviceman, deprived of his family and his local area, during his service, requires moral and spiritual support, which cannot be fully provided to him by any direct military chief or officer - tutor. After all, the army stands for clear subordination and unabashedly following the orders of direct military commanders. At the same time, since a soldier was not born as a machine but is human, not all military situations are best designed for his conscience, and moreover, in human terms, he needs spiritual care - elementary assistance not provided for by the charter, but which, however, does not contradict, but promotes high army spirit.

Despite the fact that the movement to provide pastoral care to the Ukrainian armed forces began in 1993, the issue of the chaplaincy institution and proper legal regulation remains open.

One of the first documents that defined the implementation of measures to meet the religious needs of servicemen was the Ministry of Defense of Ukraine Directive "On Organizing the Religious Issues of Soldiers of the Armed Forces of Ukraine" (Ministry of Defense of Ukraine Directive, 2006).

Since 1992, in Ukraine there has been the All-Ukrainian non-governmental organization "Union of Christians - Servicemen of Ukraine" (registered in May 2000), bringing together active military personnel, those in reserves (retired) and their families.

Training of Ukrainian chaplains began in 1999-2003. In 2008, together with representatives of religious organizations serving in the armed forces of Ukraine, a "Memorandum of understanding on cooperation in the pastoral care of military personnel of the armed forces of Ukraine" was signed.

The main purpose of implementation in the armed forces of Ukraine of an effective system of pastoral care and the creation of an institute of military clergy (chaplaincy) is to ensure the constitutional right of the personnel, which is freedom of conscience and religion, to create a healthy psychological climate 
in military collectives, families of military personnel, to strengthen the formation of military personnel. Morality and spirituality, joining forces of the Army and the Church in the proper formation of a rich inner world of the defender of country and create positive motivation for military service. Unfortunately, this has not been achieved.

In 2009, a consultative and advisory body was created under the Ministry of Defense of Ukraine - the Council for Pastoral Care, which included representatives of the seven largest denominations of Ukraine of different faiths.

In April 2011, the Ministry of Defense of Ukraine approved the Concept of pastoral care in the Armed Forces of Ukraine. The Concept defines that "pastoral care of servicemen is a type of pastoral ministry of the denomination, aimed at spiritual care and satisfaction of the religious needs of servicemen and employees of the Armed Forces of Ukraine, who, in view of the nature of their military service, in one way or another freely professing their religion and in need of spiritual care" (Minister of Defense of Ukraine Order No. 220, 2011).

The Regulation on the Service of the Clergy (Chaplaincy) in the Armed Forces of Ukraine, adopted in 2017, defines the main tasks, the order of activity of structural units (officials) of the Ministry of Defense of Ukraine, the Armed Forces of Ukraine on the organisation of activities of the military clergy (Chaplaincy) services) and the rights and responsibilities of military priests (chaplains) (Order N 677-p, 2016).

Of particular interest is the draft Law № 10244-1 “On Military Chaplaincy," which was adopted by the Verkhovna Rada of Ukraine as a basis. This project envisages the organizational and legal foundations of the interaction between the state and religious organizations (chaplain associations) on the implementation of the constitutional right of military personnel and employees of the Armed Forces of Ukraine, other legal military formations to freedom of worldview and religion through the introduction of the military chaplaincy institute. Sufficiently strict requirements have been put forward for the position of chaplain. According to the developers of the project "military chaplain - a priest (pastor) is authorized for a fixed term by a chaplain association of a religious center to provide pastoral care for the military. The clergyman must be a citizen of Ukraine, be fluent in the state language, have a full higher spiritual education, and be a member of the Chaplain's Association (which may impose other requirements). The military chaplains are authorized by the heads of the chaplain's association in agreement with the relevant unit (officer) on matters of military clergy (chaplain service) of the Armed Forces and other military formations. "A military chaplain cannot be a priest from the Russian Federation. Military chaplain can work on a volunteer basis. A volunteer may provide pastoral care for members of the Armed Forces and other military formations on a voluntary basis, if necessary, to provide religious services (cults) for believing servicemen and employees other than the religious affiliation of existing chaplain associations. The requirements for volunteer chaplains are the same as for paid priests. This bill has caused a number of comments. The legislator envisages the possibility of "recommending" to religious organizations to 
form "chaplain associations," which are absent, not with the status of religious organizations, but with an unclear legal status. Moreover, despite the fact that it is formally referred to as a "recommendation," the whole process of military chaplaincy in the project is attached to such "chaplain associations." Therefore, religious organizations that do not create such associations are denied the opportunity to participate in the military chaplaincy process. In this way, religious organizations, despite their "recommendation" for the formation of "chaplain associations," are de facto compelled to form institutions that are not peculiar to them. In addition, it restricts the ability to perform chaplaincy activities only through a pastoral care agreement (and, accordingly, a civilian employee status) and volunteer activities. Accordingly, the project does not provide the possibility of performing chaplaincy under contract as a serviceman, which in our view is incorrect.

\section{CONCLUSION}

There are no historical analogies in the world for the creation of a military chaplaincy institute under similar conditions, which makes the current Ukraine experience unique.

Despite the fact that the Institute of Military Chaplaincy in Ukraine began to revive in the early 90s of the twentieth century. The issue of state regulation in the field of pastoral care of military personnel of the Armed Forces of Ukraine and creation of an institute of military chaplaincy remained without due attention. It should be noted that Ukraine is a secular state and this has the effect on the lack of a stable state position on these issues.

The Institute of Military Chaplaincy in Poland began to revive in the early 1990 with the adoption of new legislation. The legal support for the existence of a military chaplaincy institute in Poland is provided for by the relevant state normative-legal acts and by-church documents.

Depending on the greater inclination toward the State or the Church, chaplains by their social status may be military (officers, ensigns or soldiers) or civilians. Most countries choose a mixed approach on this issue. In the army, chaplains are servicemen who provide the basic need for spiritual care, and as auxiliaries are civilian chaplains who conclude a contract of employment for a fixed term or under certain conditions. But the notion of a volunteer chaplain is inherent only in Ukrainian law.

The analysis of legal acts shows that Ukraine chooses the "European" model of chaplaincy. As a rule, chaplaincy is confessional. Each church designates its chief military chaplain (bishop). However, in chaplaincy there are only those churches whose influence on society and contribution to national culture has traditionally been significant. Their status is formed on the basis of a concordat (an agreement between the Church and the State, fixed by law). Preference is given to a "civilian" chaplaincy. 


\section{REFERENCES}

[1] Yurchuk, Е. (2014) Перспективи військового капеланства в Україні [Prospects for the military chaplaincy in Ukraine]. Retrieved from http://naub.oa.edu.ua/2014/ perspektyvy-vijskovoho-kapelanstva-v-ukrajini/

[2] Constitution of Ukraine (1996). Retrieved from https://zakon.rada.gov.ua/laws/ show $/ 254$ к/96-вр

[3] Additional Protocol to the Geneva Conventions of 12 August 1949, on the protection of victims of international armed conflicts (Protocol I), 8 June 1977. Retrieved from http://zakon2.rada.gov. ua/laws/show/995_199

[4] Vladichenko, L. (2013) Iнститут Військового капеланства в Збройних силах Польщі [Institute of Military Chaplaincy in the Armed Forces of Poland]. SKHID, 5 (125), 178-182.

[5] Dekret biskupa Józefa Guzdka ustalający przynależność parafii wojskowych do dekanatyw [Decree of Bishop Józef Guzdek determining the belonging military parishes to deaneries] (2012). Retrieved from: https://web.archive.org/web/20171023010657/http://www.ordynariat. wp.mil.pl/plik/file/2012-02-29\%20dekanaty_parafie_2012.pdf

[6] Lebedenovich, I. (1963). Полеві духівники Української Галицької Армії [Field Officers of the Ukrainian Galician Army] Retrieved from http://diasporiana.org.ua/wp-content/uploads/ books/7207/ file.pdf

[7] Regarding issues meeting the religious needs of the military of the Armed Forces of Ukraine: approved by the Ministry of Defense of Ukraine Directive № D-25 (21.04.2006). Retrieved from https:/ / www.irs.in.ua index.php?view $=$ article\&catid $=63 \% 3$ Ava\&id $=472 \% 3 \mathrm{~A} 1 \&$ format $=$ pdf\&option $=$ com_content\&Itemid $=86 \&$ lang $=$ ru

[8] On approval of the concept of pastoral care in the Armed Forces of Ukraine: order of the Minister of Defense of Ukraine No. 220. Retrieved April 22, 2011, from https://www.irs.in.ua/index. php?option $=$ com_content\&view $=$ article\&id $=861 \% 3 \mathrm{~A} 1 \&$ catid $=63 \% 3$ Ava\&Itemid $=86 \& l a n g$ $=\mathrm{ru}$

[9] On the service of the clergy (chaplaincy service) in the Armed Forces, the National Guard and the State Border Service. Order N 677-p. Retrieved April 14, 2016, from https://www.irs.in.ua/index. php?option $=$ com_content\&view $=$ article\&id $=1854 \% 3 \mathrm{~A} 1 \&$ catid $=63 \% 3$ Ava\&Itemid $=86 \&$ lang $=\mathrm{ru}$ 